\title{
Ponto de encontro na rede virtual: editores discutem experiências e trocam idéias
}

\author{
On line meeting point: editors discuss \\ experiences and exchange ideas
}

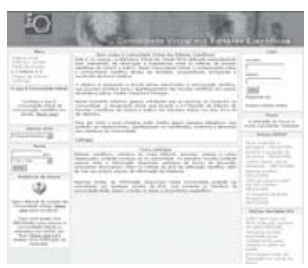

http://cvirtualccs.bvsalud.org/tikicustom_home.php
Drofissionais envolvidos com a publicação de revistas científicas con1 tam com um novo espaço de discussão na Internet. Se você ainda não conhece a "Comunidade virtual dos editores científicos" vale a pena conferir em http://cvirtual-ccs.bvsalud.org. Trata-se de um nicho na Biblioteca Virtual em Saúde da Bireme, em que o objetivo é a troca de experiências visando o aperfeiçoamento das revistas científicas e a facilidade na comunicação entre pesquisadores.

Há várias alternativas de navegação na página que, logo no início, propõe que o visitante faça o seu registro, que requer apenas o nome e senha. Qualquer um pode acessar a página mas apenas os membros inscritos terão acesso a todas as suas áreas e documentos. Há várias seções, como a "Notícias", que veicula notas e informações sobre o universo da comunicação científica, especialmente na área da saúde e medicina. Você não só lê como edita e divulga sua própria notícia e, depois, poderá verificar sua repercussão no ranking. As notícias são remetidas ao moderador da página, que aprova ou não cada uma delas, que acabam sendo classificadas como: Iniciativas, Eventos, Documentos, Artigos científicos e Novas Revistas. Outras seções são "Fórum" de debates, "Galeria de Imagens"e "Área Pessoal", que permite ao usuário personalizar seu ambiente de trabalho e, caso todos os campos sejam preenchidos, navegar pela Comunidade Virtual devidamente identificado, aé mesmo com uma fotografia anexada.

Entre os documentos disponíveis na Comunidade Virtual de Editores Científicos recomendamos a leitura do "Guia do Usuário", altamente amigável e de fácil compreensão, que descreve as possibilidades e ensina como utilizar o site. Não deixe de participar.

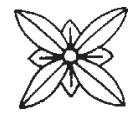




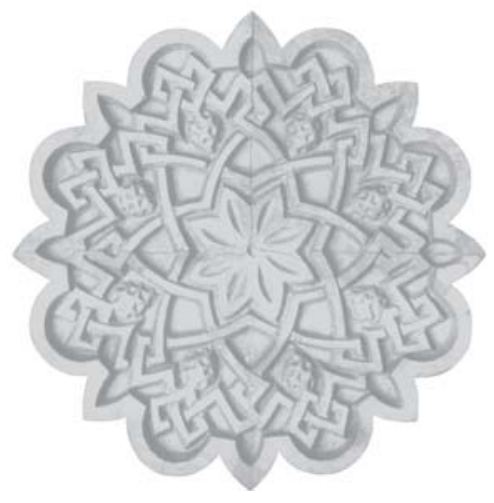

